Article

\title{
Purification and Characterization of Antioxidant Peptides Derived from Protein Hydrolysate of the Marine Bivalve Mollusk Tergillarca granosa
}

\author{
Xiu-Rong Yang ${ }^{1}$, Yi-Ting Qiu ${ }^{2}$, Yu-Qin Zhao ${ }^{2}$, Chang-Feng Chi ${ }^{1, *}$ and Bin Wang ${ }^{2, *}$ \\ 1 National and Provincial Joint Laboratory of Exploration and Utilization of Marine Aquatic Genetic \\ Resources, National Engineering Research Center of Marine Facilities Aquaculture, School of Marine Science \\ and Technology, Zhejiang Ocean University, Zhoushan 316022, China; yxr1948008999@163.com \\ 2 Zhejiang Provincial Engineering Technology Research Center of Marine Biomedical Products, School of Food \\ and Pharmacy, Zhejiang Ocean University, Zhoushan 316022, China; qytdezh@icloud.com (Y.-T.Q.); \\ zhaoy@hotmail.com (Y.-Q.Z.) \\ * Correspondence: chichangfeng@hotmail.com (C.-F.C.); wangbin4159@hotmail.com (B.W.); \\ Tel./Fax: +86-580-255-4818 (C.-F.C.); Tel./Fax: +86-580-255-4781 (B.W.)
}

Received: 28 March 2019; Accepted: 25 April 2019; Published: 27 April 2019

\begin{abstract}
In this report, protein hydrolysate (TGH) of blood cockle (Tegillarca granosa) was prepared using a two-enzyme system (Alcalase treatment for $1.5 \mathrm{~h}$ following Neutrase treatment for $1.5 \mathrm{~h}$ ). Subsequently, six antioxidant peptides were isolated from TGH using ultrafiltration and chromatography methods, and their amino acid sequences were identified as EPLSD, WLDPDG, MDLFTE, WPPD, EPVV, and CYIE with molecular weights of 559.55, 701.69, 754.81, 513.50, 442.48, and 526.57 Da, respectively. In which, MDLFTE and WPPD exhibited strong scavenging activities on DPPH radical $\left(\mathrm{EC}_{50}\right.$ values of $0.53 \pm 0.02$ and $0.36 \pm 0.02 \mathrm{mg} / \mathrm{mL}$, respectively), hydroxy radical (EC $\mathrm{E}_{50}$ values of $0.47 \pm 0.03$ and $0.38 \pm 0.04 \mathrm{mg} / \mathrm{mL}$, respectively), superoxide anion radical (EC $\mathrm{E}_{50}$ values of $0.75 \pm 0.04$ and $0.46 \pm 0.05 \mathrm{mg} / \mathrm{mL}$, respectively), and ABTS cation radical (EC 50 values of $0.96 \pm 0.08$ and $0.54 \pm 0.03 \mathrm{mg} / \mathrm{mL}$, respectively). Moreover, MDLFTE and WPPD showed high inhibiting ability on lipid peroxidation. However, MDLFTE and WPPD were unstable and could not retain strong antioxidant activity at high temperatures $\left(>80^{\circ} \mathrm{C}\right.$ for $\left.0.5 \mathrm{~h}\right)$, basic $\mathrm{pH}$ conditions $(\mathrm{pH}>9$ for $2.5 \mathrm{~h})$, or during simulated GI digestion. In addition, the effect of simulated gastrointestinal digestion on TGP4 was significantly weaker than that on MDLFTE. Therefore, MDLFTE and WPPD may be more suitable for serving as nutraceutical candidates in isolated forms than as food ingredient candidates in functional foods and products.
\end{abstract}

Keywords: blood cockle (Tegillarca granosa); protein hydrolysate; bioactive peptide; antioxidant activity

\section{Introduction}

Toxic reactive oxygen species (ROS) induced by oxidative stress destroy structures of some functional biomacromolecules including DNA, proteins, and membrane lipids, which further lead to some chronic diseases, such as liver damage, type 2 diabetes, asthma, neurodegenerative diseases, and arthritis [1-3]. In addition, oxidative deterioration produces some off-flavors and harmful lipid metabolites, which negatively influence the food quality and somatic functions [2,4]. Therefore, eliminating superfluous ROS is important for keeping cellular homeostasis. At present, people often use synthetic antioxidants to prevent and intervene ROS damage, but the negative effects of synthetic antioxidants, including liver damage and carcinogenesis, limit their scope of usage and dosage $[5,6]$. 
Therefore, looking for nontoxic natural antioxidants is of great significance for food, cosmetic, and pharmaceutical industries.

Bioactive peptides (BPs), which in general range from 2 to 20 amino acids in size, are fragments of proteins and become active when released during enzymatic hydrolysis, gastrointestinal transit, and fermentation [7,8]. Recently, BPs released from proteins of aquatic products and their by-products have been demonstrated to show multiple biological properties, including hypolipidemic, angiotensin-converting-enzyme (ACE) inhibitory, antioxidative, anti-diabetic, and immunomodulatory activities [9-12]. Furthermore, there is growing interest worldwide in discovering antioxidant peptides (APs) from food proteins and applying them in functional foods and nutraceuticals due to their biological and nutritional properties [5]. HPLDSLCL from protein hydrolysate of ark shell (Scapharca subcrenata) showed potent 2,2-diphenyl-1-picrylhydrazyl (DPPH) and 2,20-azino-bis-3-ethylbenzothiazoline-6-sulfonic acid (ABTS) cation radical scavenging activities, reducing power, and oxidative inhibition on copper-catalyzed human low-density lipoprotein [13]. AAVPSGASTGIYEALELR (molecular weight (MW) of $1805.03 \mathrm{Da}$ ) and NPLLEAFGNAK (MW of $1173.34 \mathrm{Da}$ ) isolated from gonad hydrolysate of purple sea urchin can activate DAF-16 pathway and increase the expression of DAF-16 target genes, which further reduce ROS level and the expression of heat shock protein-16.2 and superoxide dismutase-3 (SOD-3) in oxidation-damaged nematodes [14]. SDITRPGNM from protein hydrolysate of Palmaria palmata has potential applications as a food preservative and health enhancing ingredient because of its high reducing power and oxygen radical absorbance capacity [4]. Wong et al. reported that WAFAPA and MYPGLA from blue-spotted stingray showed stronger inhibiting ability than that of carnosine on $\mathrm{H}_{2} \mathrm{O}_{2}$-induced lipid oxidation and could protect plasmid DNA and proteins from oxidative damage induced by Fenton's reagent. In addition, $\mathrm{EC}_{50}$ (half elimination ratio) value of WAFAPA $(8.33 \mathrm{mg} / \mathrm{mL})$ on ABTS cation radical was lower than that of MYPGLA $(12.88 \mathrm{mg} / \mathrm{mL})$ [15]. Yang et al. reported that GADIVA and GAEGFIF from gelatin hydrolysate of skipjack tuna bone might serve as potential candidates in health-promoting food industries due to their strong antioxidant activities, including lipid peroxidation inhibition ability, radical scavenging activity, and reducing power [16]. Therefore, BPs isolated from seafoods and their by-products exhibit significant antioxidant activity in protecting living organism from oxidative damage.

Blood cockle (Tegillarca granosa), which resides along the estuarine and coastal regions of the Indo-Pacific, pertains to the Arcidae family, and is one significantly economic bivalve species [17]. In south provinces of China, blood cockle is an important and nutritious festival food and its large-scale aquaculture production has been practiced. In addition, blood cockles have been served as traditional medicine for regulating the secretion of human gastric acid and curing inflammation, stomachache, anemia, and cancers $[17,18]$. Furthermore, Han et al. reported that polypeptides (MW ranged between 1000 and $5000 \mathrm{Da}$ ) from T. granosa showed significant antitumor activity and could improve immune responses without significant toxic side effects, which suggested that those polypeptides might be suitable for combination therapy of cancer patients [19]. In our previous work, two APs including Trp-Pro-Pro (WPP) and Gln-Pro (QP) were isolated and identified from Neutrase hydrolysate of T. granosa protein, and WPP has the potential to serve as a natural antioxidant and anticancer agent for the nutraceutical and pharmaceutical industries because of its high radical scavenging activity and strong cytotoxicity toward PC-3, DU-145, H-1299, and HeLa cell lines [17]. However, past studies have not provided enough support for promoting the application of blood cockle in functional food and products. In order to make full use of these resources and look for nontoxic natural antioxidants, the aims of this work were to (i) prepare and characterize APs from protein hydrolysate of blood cockle (TGH) and (ii) evaluate the stability and in vitro antioxidant activity of the isolated APs. 


\section{Results and Discussion}

\subsection{Purification of APs from $T G H$}

\subsubsection{Preparation and Fractionation of TGH}

Defatted muscle of blood cockle was hydrolyzed under a two-enzyme system (Alcalase treatment for $1.5 \mathrm{~h}$ following Neutrase treatment for $1.5 \mathrm{~h}$ ), and the degree of hydrolysis (DH) and yield of the resulted hydrolysate (referred to as TGH) were $19.32 \pm 1.37 \%$ and $9.62 \pm 0.86 \%$ (on the basis of defatted muscle), respectively. In addition, TGH could strongly scavenge DPPH radical with $\mathrm{EC}_{50}$ value of $3.55 \pm 0.32 \mathrm{mg}$ protein $/ \mathrm{mL}$, which was lower than those of protein hydrolysates from miiuy croaker muscle $(<50 \%$ at $5 \mathrm{mg} / \mathrm{mL})$ [2] and swim bladder $(13.55 \mathrm{mg} / \mathrm{mL})$ [11], bluefin leatherjacket head $(15.98 \%$ at $10 \mathrm{mg} / \mathrm{mL}$ ) [20], and tilapia skin $(3.66 \mathrm{mg} / \mathrm{mL})$ [21], but higher than those of protein hydrolysates of sea urchin gonad $(0.945 \mathrm{mg} / \mathrm{mL})$ [14] and salmon pectoral fin $(1.63 \mathrm{mg} / \mathrm{mL})$ [22].

TGH was further fractionized with MW Cut Off (MWCO) membranes of 3, 5, and $10 \mathrm{kDa}$, and four fractions including TGH-I(<3 kDa), TGH-II (3-5 kDa), TGH-III (5-10 kDa), and TGH-IV (>10 kDa) were prepared. The $\mathrm{EC}_{50}$ value of TGH-Ion DPPH radical was $2.83 \pm 0.17 \mathrm{mg}$ protein $/ \mathrm{mL}$, which was significantly $(P<0.05)$ stronger than those of TGH $(3.55 \mathrm{mg}$ protein/mL), TGH-II $(5.28 \pm 0.35 \mathrm{mg}$ protein/mL), TGH-III (7.58 $\pm 0.32 \mathrm{mg}$ protein/mL), and TGH-IV (9.36 $\pm 0.54 \mathrm{mg}$ protein/mL). TGH was composed of different chain length peptides. Short peptides are more accessible and trap the free radicals more easily [5,23]. The DPPH radical activity of TGH and its fractions were in accordance with previous literature that the antioxidant abilities of protein hydrolysates were negatively correlated with their average MW [24]. Therefore, TGH-Iaccounting for $13.24 \pm 1.23 \%$ of TGH was selected for the subsequent chromatographic separation.

\subsubsection{Chromatography Isolation of APs from TGH-I}

As shown in Figure 1A, six fractions (TGH-I-1 to TGH-I-6) were separated from TGH-Iusing a DEAE-52 cellulose column. In which, TGH-I-1 was eluted using deionized water (DW); TGH-I-2 and TGH-I-3 were eluted using $0.1 \mathrm{M} \mathrm{NaCl}$; TGH-I-4 and TGH-I-5 were eluted using $0.5 \mathrm{M} \mathrm{NaCl}$;

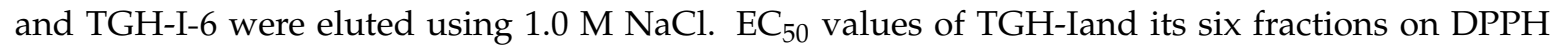
radical were showed in Figure $1 \mathrm{~B}$, and the data demonstrated that TGH-I-5 with $\mathrm{EC}_{50}$ value of $2.29 \pm 0.11 \mathrm{mg}$ protein/mL showed significantly stronger DPPH radical scavenging activity than those of TGH-I (2.82 $\pm 0.16 \mathrm{mg}$ protein/mL), TGH-I-1 $(9.68 \pm 0.42 \mathrm{mg}$ protein/mL), TGH-I-2 $(4.39 \pm 0.25 \mathrm{mg}$ protein/mL), TGH-I-3 (6.04 $\pm 0.28 \mathrm{mg}$ protein/mL), TGH-I-4 (3.65 $\pm 0.17 \mathrm{mg}$ protein/mL), and TGH-I-6 $(7.53 \pm 0.36 \mathrm{mg}$ protein $/ \mathrm{mL})(p<0.05)$. Ion exchange resins with different kinds of ionic forms and particle sizes are applied for the preparation of charged compounds and wiping off ionic molecules [17]. Functional molecules with negatively charges can bind to positively charged resins on Van der Waals forces and be separated from mixture solutions [25]. Then, TGH-I-5 with a yield of $10.43 \pm 0.76 \%$ of TGH-Iwill be used for the subsequent experiment.

TGH-I-5 was further fractionized into three fractions (TGH-I-5A, TGH-I-5B, and TGH-I-5C) using a Sephadex G-25 column (Figure 2A). The EC $_{50}$ value of TGH-I-5B on DPPH radical was $1.68 \pm 0.12 \mathrm{mg}$ protein/mL, which was significantly $(p<0.05)$ lower than those of TGH-I-5 $(2.29 \pm 0.11 \mathrm{mg}$ protein $/ \mathrm{mL})$, TGH-I-5A (4.38 $\pm 0.25 \mathrm{mg}$ protein/mL), and TGH-I-5C (3.57 $\pm 0.21 \mathrm{mg}$ protein/mL) (Figure 2B). Subsequently, TGH-I-5B accounting for $30.94 \pm 2.62 \%$ of TGH-I-5 was separated into four fractions (TGH-I-5B1 to TGH-I-5B4) using Sephadex G-15 column (Figure 3A) and their antioxidant activity are presented in Figure 3B. The $\mathrm{EC}_{50}$ value of TGH-I-5B3 on DPPH radical was $1.25 \pm 0.10 \mathrm{mg}$ protein $/ \mathrm{mL}$, which was significantly $(p<0.05)$ higher than those of TGH-I-5B $(1.68 \pm 0.12 \mathrm{mg}$ protein/mL $)$, TGH-I-5B1 (3.69 $\pm 0.23 \mathrm{mg}$ protein/mL), TGH-I-5B2 $(2.47 \pm 0.18 \mathrm{mg}$ protein $/ \mathrm{mL})$, and TGH-I-5B4 $(4.37 \pm 0.26 \mathrm{mg}$ protein/mL). Therefore, TGH-I-5B3 accounting for $18.62 \pm 1.33 \%$ of TGH-I-5B was suitable for the following separation process. 

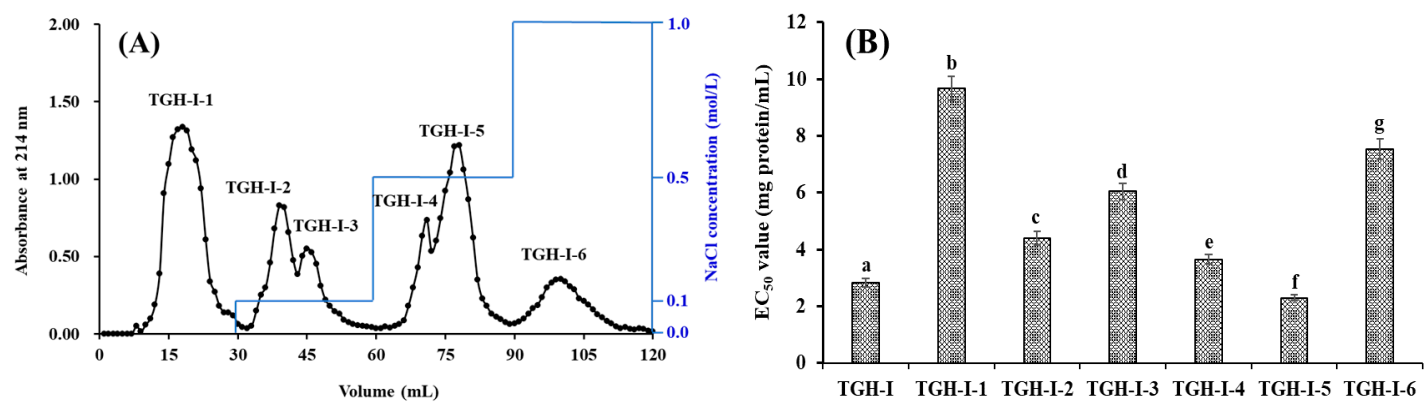

Figure 1. Elution profile of TGH-Iin DEAE-52 cellulose anion-exchange chromatography (A) and EC 50 values of TGH-1 and its fractions on DPPH radical (B). TGH-I-1 collected from $10 \mathrm{~mL}$ to $27 \mathrm{~mL}$; TGH-I-2 collected from $34 \mathrm{~mL}$ to $42 \mathrm{~mL}$; TGH-I-3 collected from $43 \mathrm{~mL}$ to $51 \mathrm{~mL}$; TGH-I-4 collected from $65 \mathrm{~mL}$ $72 \mathrm{~mL}$; TGH-I-5 collected from $73 \mathrm{~mL}$ to $85 \mathrm{~mL}$; and TGH-I-6 collected from $92 \mathrm{~mL}$ to $110 \mathrm{~mL}$. All data are expressed as mean \pm standard deviation ( $S D, n=3)$. a-g values with the same letters indicate no significant difference of different sample $(p>0.05)$.
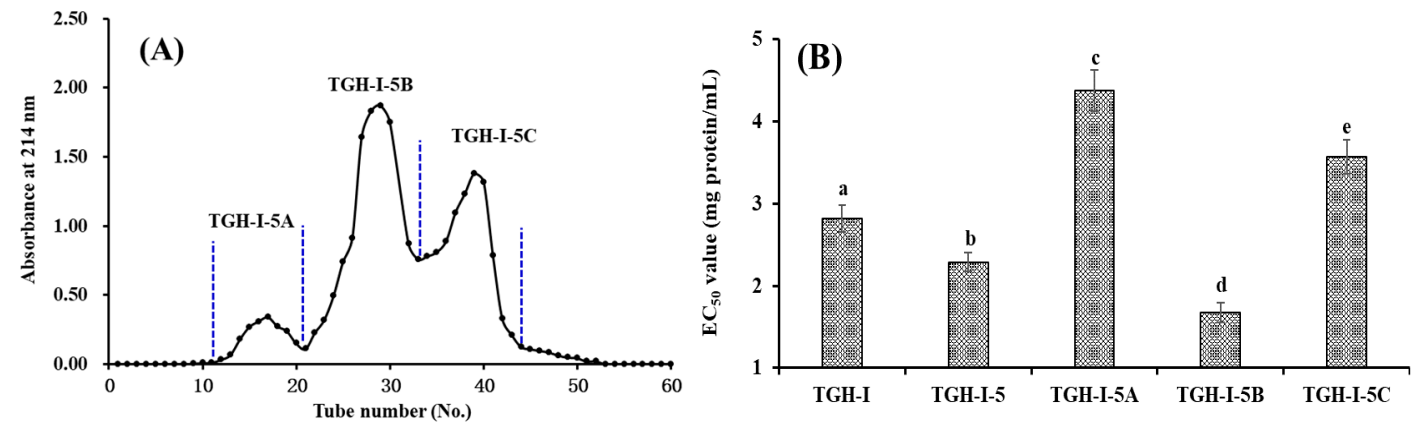

Figure 2. Elution profile of TGH-I-5 in Sephadex G-25 column (A) and $\mathrm{EC}_{50}$ values of TGH-1-5 and its fractions on DPPH radical (B). TGH-1-5A collected from No. 11 to 21; TGH-1-5B collected from No. 22 to 32; and TGH-1-5C collected from No. 33 to 43. All data are expressed as mean \pm SD (n=3). a-e values with the same letters indicate no significant difference of different sample $(p>0.05)$.
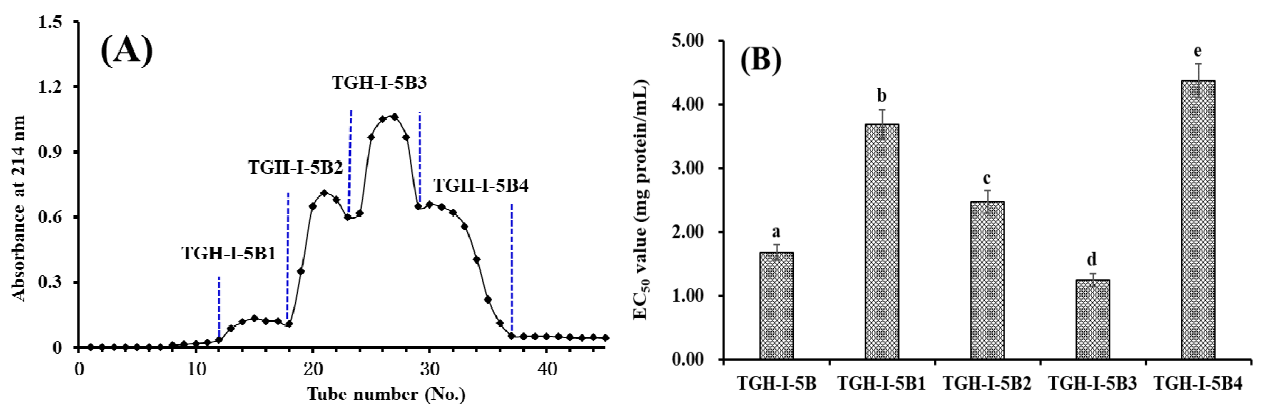

Figure 3. Elution profile of TGH-I-5B in Sephadex G-15 column (A) and EC 50 values of TGH-1-5B and its fractions on DPPH radical (B). TGH-1-5B1 collected from No. 12 to 18; TGH-1-5B2 collected from No. 19 to 23; TGH-1-5B3 collected from No. 24 to 29; and TGH-1-5B4 collected from No. 30 to 37. All data are expressed as mean $\pm \mathrm{SD}(\mathrm{n}=3)$. a-e values with same letters indicate no significant difference of different sample $(p>0.05)$.

As shown in Figure 4, six APs with a retention time of $8.586 \mathrm{~min}$ (TGP-1), $9.831 \mathrm{~min}$ (TGP-2), $10.679 \mathrm{~min}$ (TGP-3), $12.394 \mathrm{~min}$ (TGP-4), $12.692 \mathrm{~min}$ (TGP-5), and $13.762 \mathrm{~min}$ (TGP-6) were isolated from TGH-I-5B3 using an HPLC system with a Zorbax C-18 column (Table 1), and the eluted peptides were collected separately on their chromatographic peaks and lyophilized for analysis of the amino acid sequences, antioxidant activities, and stability properties. In addition, the yields of six isolated APs were $40.52 \pm 3.76 \mathrm{mg} / 100 \mathrm{~g}$ TGH (TGP-1), $9.43 \pm 0.64 \mathrm{mg} / 100 \mathrm{~g}$ TGH (TGP-2), 
$23.46 \pm 1.51 \mathrm{mg} / 100 \mathrm{~g}$ TGH (TGP-3), $12.35 \pm 1.24 \mathrm{mg} / 100 \mathrm{~g}$ TGH (TGP-4), $67.88 \pm 1.33 \mathrm{mg} / 100 \mathrm{~g}$ TGH (TGP-5), and $5.93 \pm 0.61 \mathrm{mg} / 100 \mathrm{~g}$ TGH (TGP-6), respectively (Table 1).

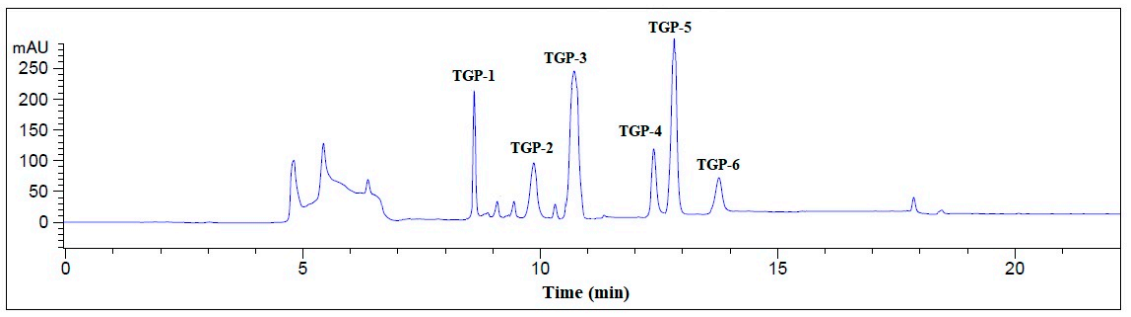

Figure 4. Elution profile of TGH-I-5B3 separated by RP-HPLC system on a Zorbax C-18 column $(4.6 \times 250 \mathrm{~mm})$ from 0 to $25 \mathrm{~min}$.

Table 1. Retention time ( $\mathrm{min}$ ), yields (mg/100 g TGH), amino acid sequences, and molecular masses (Da) of six APs (TGP1-TGP6) from protein hydrolysate of blood cockle (T. granosa).

\begin{tabular}{ccccc}
\hline No. & $\begin{array}{c}\text { Retention } \\
\text { Time }(\mathbf{m i n})\end{array}$ & $\begin{array}{c}\text { Yield } \\
\mathbf{( m g} / \mathbf{1 0 0} \mathbf{g} \text { TGH) }\end{array}$ & Amino Acid Sequence & $\begin{array}{c}\text { Theoretical Mass/ } \\
\text { Observed Mass (Da) }\end{array}$ \\
\hline TGP-1 & 8.586 & $40.52 \pm 3.76$ & Glu-Pro-Leu-Ser-Asp (EPLSD) & $559.57 / 559.55$ \\
TGP-2 & 9.831 & $9.43 \pm 0.64$ & Trp-Ile-Asp-Pro-Asp-Gly (WLDPDG) & $701.72 / 701.69$ \\
TGP-3 & 10.679 & $23.46 \pm 1.51$ & Met-Asp-Leu-Phe-Thr-Glu (MDLFTE) & $754.85 / 754.81$ \\
TGP-4 & 12.394 & $12.35 \pm 1.24$ & Trp-Pro-Pro-Asp (WPPD) & $513.54 / 513.50$ \\
TGP-5 & 12.692 & $67.88 \pm 1.33$ & Glu-Pro-Val-Val (EPVV) & $442.51 / 442.48$ \\
TGP-6 & 13.762 & $5.93 \pm 0.61$ & Cys-Tyr-Ile-Glu (CYIE) & $526.60 / 526.57$ \\
\hline \multicolumn{5}{c}{ The yields of six APs (TGP1-TGP6) are expressed as mean \pm SD (n=3). }
\end{tabular}

\subsection{Amino Acid Sequence Analysis and Mass Spectrometry of APs (TGP1-TGP6)}

The amino acid sequences and molecular mass of six APs (TGP1-TGP6) were determined using a protein sequencer and electrospray ionization (ESI)-mass spectrometer (MS), and the data are shown in Table 1. The amino acid sequences of six APs (TGP1-TGP6) were identified as Glu-Pro-Leu-Ser-Asp (EPLSD, TGP-1), Trp-Ile-Asp-Pro-Asp-Gly (WLDPDG, TGP-2), Met-Asp-Leu-Phe-Thr-Glu (MDLFTE, TGP-3), Trp-Pro-Pro-Asp (WPPD, TGP-4), Glu-Pro-Val-Val (EPVV, TGP-5), and Cys-Tyr-Ile-Glu (CYIE, TGP-6) with MWs of 559.55, 701.69, 754.81, 513.50, 442.48, and $526.57 \mathrm{Da}$, respectively, which were in well accordance with their theoretical masses (Table 1).

\subsection{Antioxidant Activity}

To better evaluate the activity of six APs (TGP1-TGP6) from blood cockle (T. granosa), four kinds of radical scavenging assays and lipid peroxidation inhibition assay were employed, and the data were presented in Table 2 and Figures 5 and 6.

Table 2. Radical scavenging activity of six isolated APs (TGP1-TGP6) from protein hydrolysate of blood cockle (T. granosa).

\begin{tabular}{ccccc}
\hline & \multicolumn{3}{c}{ Half Elimination Ratio $\left(\mathrm{EC}_{\mathbf{5 0}}, \mathbf{m g} / \mathbf{m L}\right)$} \\
\cline { 2 - 5 } No. & DPPH Radical & Hydroxyl Radical & $\begin{array}{c}\text { Superoxide Anion } \\
\text { Radical }\end{array}$ & $\begin{array}{c}\text { ABTS Cation } \\
\text { Radical }\end{array}$ \\
\hline TGP-1 & $1.23 \pm 0.09^{\mathrm{a}, \mathrm{b}}$ & $2.18 \pm 0.16^{\mathrm{a}}$ & $2.04 \pm 0.23^{\mathrm{a}}$ & $3.28 \pm 0.17^{\mathrm{a}}$ \\
TGP-2 & $1.82 \pm 0.16^{\mathrm{c}}$ & $1.54 \pm 0.11^{\mathrm{b}}$ & $2.49 \pm 0.17^{\mathrm{b}}$ & $2.56 \pm 0.23^{\mathrm{b}}$ \\
TGP-3 & $0.53 \pm 0.02^{\mathrm{d}}$ & $0.47 \pm 0.03^{\mathrm{c}}$ & $0.75 \pm 0.04^{\mathrm{c}}$ & $0.96 \pm 0.08^{\mathrm{c}}$ \\
TGP-4 & $0.36 \pm 0.02^{\mathrm{e}}$ & $0.38 \pm 0.04^{\mathrm{c}}$ & $0.46 \pm 0.05^{\mathrm{d}}$ & $0.54 \pm 0.03^{\mathrm{d}}$ \\
TGP-5 & $1.13 \pm 0.14^{\mathrm{a}}$ & $1.09 \pm 0.08^{\mathrm{d}}$ & $1.69 \pm 0.14^{\mathrm{e}}$ & $2.54 \pm 0.17^{\mathrm{b}}$ \\
TGP-6 & $1.30 \pm 0.11^{\mathrm{b}}$ & $1.29 \pm 0.13^{\mathrm{b}}$ & $2.31 \pm 0.15^{\mathrm{b}}$ & $1.86 \pm 0.15^{\mathrm{e}}$ \\
\hline
\end{tabular}

All data are expressed as mean $\pm \mathrm{SD}(\mathrm{n}=3)$. ${ }^{\mathrm{a}-\mathrm{e}}$ Values with same letters indicated no significant difference of different sample at same radicals $(p>0.05)$. 

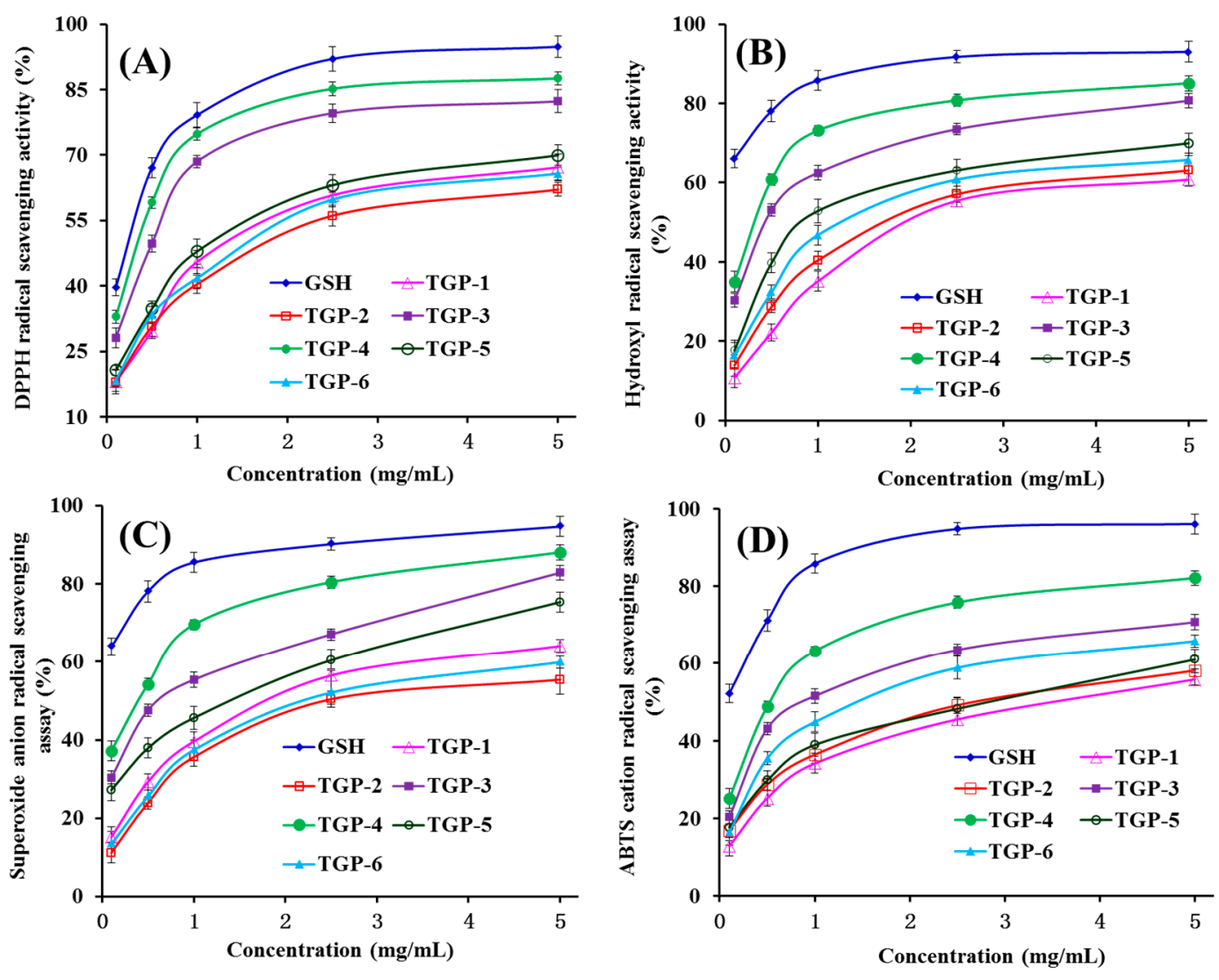

Figure 5. DPPH (A), hydroxyl (B), superoxide anion (C), and ABTS cation (D) radical scavenging activities of six APs (TGP1-TGP6) from protein hydrolysate of blood cockle (T. granosa). All data are expressed as mean $\pm \mathrm{SD}(\mathrm{n}=3)$.

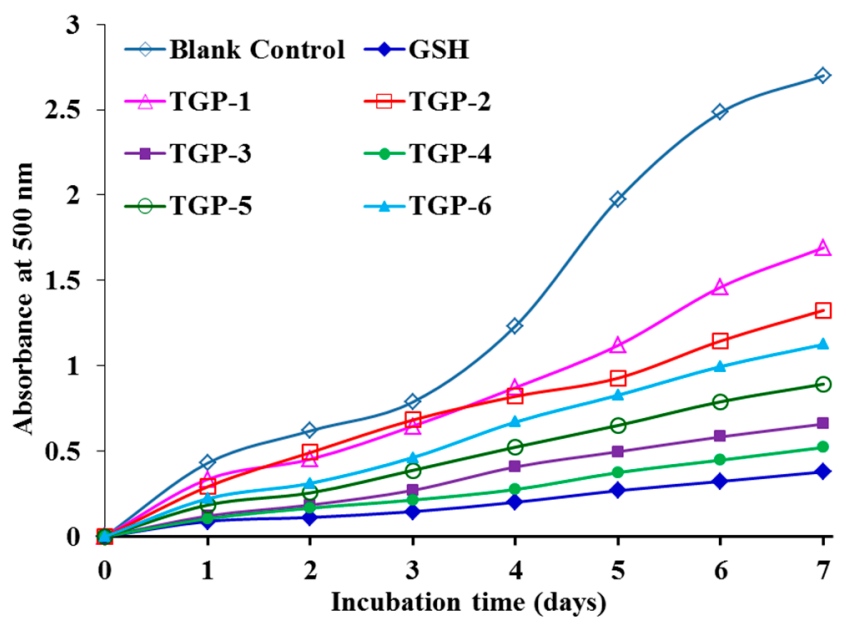

Figure 6. Lipid peroxidation inhibition assays of six APs (TGP1-TGP6) from protein hydrolysate of blood cockle (T. granosa). All data are expressed as mean $\pm \mathrm{SD}(\mathrm{n}=3)$.

\subsubsection{Radical Scavenging Activity}

DPPH Radical Scavenging Activity

As shown in Figure 5A, six APs (TGP1-TGP6) showed strong DPPH radical scavenging activities with a positive correlation between the activity and the concentration, but TGP1-TGP6 still showed weaker activity than the positive control of GSH did at the same concentration. $\mathrm{EC}_{50}$ values of TGP3 and TGP4 were $0.53 \pm 0.02 \mathrm{mg} / \mathrm{mL}$ and $0.36 \pm 0.02 \mathrm{mg} / \mathrm{mL}$, respectively, which were significantly lower 
than those of TGP-1 $(1.23 \pm 0.09 \mathrm{mg} / \mathrm{mL})$, TGP-2 $(1.82 \pm 0.16 \mathrm{mg} / \mathrm{mL})$, TGP-5 $(1.13 \pm 0.14 \mathrm{mg} / \mathrm{mL})$, and TGP-6 $(1.30 \pm 0.11 \mathrm{mg} / \mathrm{mL})$, respectively. In addition, the $\mathrm{EC}_{50}$ values of TGP3 and TGP4 were lower than those of APs from protein hydrolysates of miiuy croaker muscle (FWKVV: $0.85 \mathrm{mg} / \mathrm{mL}$; FMPLH: $0.48 \mathrm{mg} / \mathrm{mL}$ ) [2] and swim bladder (GIEWA: $0.78 \mathrm{mg} / \mathrm{mL}$ ) [26], blue mussel (YPPAK: $2.62 \mathrm{mg} / \mathrm{mL}$ ) [27], and skipjack tuna bone (GADIVA: $0.57 \mathrm{mg} / \mathrm{mL}$ ) [16]. However, the EC 50 values of TGP3 and TGP4 were higher than those of APs from protein hydrolysates of skipjack tuna bone (GAEGFIF: $0.30 \mathrm{mg} / \mathrm{mL}$ ) [16], skate muscle (NWDMEKIWD: $0.289 \mathrm{mg} / \mathrm{mL}$ ) [28], bluefin leatherjacket skin (FIGP: $0.118 \mathrm{mg} / \mathrm{mL}$ ) [29], and grass carp skin (HFGBPFH: $0.20 \mathrm{mg} / \mathrm{mL}$ ) [30], respectively. DPPH is popularly employed to evaluate the antioxidant ability of APs due to its cell-permeable and stable properties. Therefore, six APs (TGP1-TGP6), especially TGP3 and TGP4 had the strong ability to serve as hydrogen donors or free radical scavengers for preventing the chain reaction of DPPH radical.

\section{Hydroxyl Radical Scavenging Activity}

Figure 5B indicated that six APs (TGP1-TGP6) showed concentration-related efficiency in the scavenging activity of hydroxyl radical at concentrations ranging between 0.1 and $5.0 \mathrm{mg} / \mathrm{mL}$. $\mathrm{EC}_{50}$ values of TGP3 $(0.47 \pm 0.03 \mathrm{mg} / \mathrm{mL})$ and TGP4 $(0.38 \pm 0.04 \mathrm{mg} / \mathrm{mL})$ were significantly $(p<0.05)$ lower than those of TGP1 $(2.18 \pm 0.16 \mathrm{mg} / \mathrm{mL})$, TGP2 $(1.54 \pm 0.11 \mathrm{mg} / \mathrm{mL})$, TGP5 $(1.09 \pm 0.08 \mathrm{mg} / \mathrm{mL})$, and TGP6 $(1.29 \pm 0.13 \mathrm{mg} / \mathrm{mL})$, respectively. However, the scavenging activity of TGP1-TGP6 was still lower than that of the positive control (GSH). EC 50 values of TGP3 and TGP4 were lower than those of APs from protein hydrolysates of miiuy croaker muscle (FWKVV: $0.97 \mathrm{mg} / \mathrm{mL}$; FMPLH: $0.80 \mathrm{mg} / \mathrm{mL}$ ) [2] and swim bladder (FPYLRH: $0.68 \mathrm{mg} / \mathrm{mL}$; GIEWA: $0.71 \mathrm{mg} / \mathrm{mL}$ ) [26], grass carp skin (PYSFK: $2.283 \mathrm{mg} / \mathrm{mL}$; VGGRP: $2.055 \mathrm{mg} / \mathrm{mL}$ ) [30], weatherfish loach (PSYV: $2.64 \mathrm{mg} / \mathrm{mL}$ ) [31], hairtail muscle (KA: $1.740 \mathrm{mg} / \mathrm{mL}$; AKG: $2.378 \mathrm{mg} / \mathrm{mL}$; IYG: $2.498 \mathrm{mg} / \mathrm{mL}$ ) [32], giant squid (NADFGLNGLEGLA: $0.612 \mathrm{mg} / \mathrm{mL}$ ) [33], and conger eel (LGLNGDDVN: $0.687 \mathrm{mg} / \mathrm{mL}$ ) [34]. However, $\mathrm{EC}_{50}$ values of TGP3 and TGP4 were higher than those of APs from skipjack tuna bone (GADIVA: $0.25 \mathrm{mg} / \mathrm{mL}$; GAEGFIF: $0.32 \mathrm{mg} / \mathrm{mL}$ ) [16], monkfish muscle (EWPAQ: $0.269 \mathrm{mg} / \mathrm{mL}$; FLHRP: $0.114 \mathrm{mg} / \mathrm{mL}$; LMGQW: $0.040 \mathrm{mg} / \mathrm{mL}$ ) [35], croceine croaker scale (GFRGTIGLVG: $0.293 \mathrm{mg} / \mathrm{mL}$, GPAGPAG: $0.240 \mathrm{mg} / \mathrm{mL}$, and GFPSG: $0.107 \mathrm{mg} / \mathrm{mL}$ ) [6], and spotless smoothhound (Mustelus griseus) muscle (GIISH: $0.0769 \mathrm{mg} / \mathrm{mL}$; ELLI: $0.1173 \mathrm{mg} / \mathrm{mL}$; KFPE: $0.1510 \mathrm{mg} / \mathrm{mL}$ ) [36]. Hydroxyl radicals can initiate the oxidative stress process through promptly attacking and indiscriminately oxidizing biomacromolecules in an organism. The data indicated that TGP3 and TGP4 could serve as scavengers for weakening the biological system damage of hydroxyl radical.

\section{Superoxide Anion Radical Scavenging Activity}

Figure 5C indicated six APs (TGP1-TGP6) strongly scavenge superoxide anion radical with a concentration-related efficiency manner at a concentration ranging $0.1-5.0 \mathrm{mg} / \mathrm{mL}$, but their scavenging activities were still lower than that of $\mathrm{GSH}_{\text {. }} \mathrm{EC}_{50}$ values of TGP1-TGP6 were $2.04 \pm 0.23,2.49 \pm 0.17$, $0.75 \pm 0.04,0.46 \pm 0.05,1.69 \pm 0.14$, and $2.31 \pm 0.15 \mathrm{mg} / \mathrm{mL}$, respectively. $\mathrm{EC}_{50}$ values of TGP3 and TGP4 were lower than those of APs from protein hydrolysates of miiuy croaker muscle (NFWWP: $0.84 \mathrm{mg} / \mathrm{mL}$; YFLWP: $3.08 \mathrm{mg} / \mathrm{mL}$ ) [2] and swim bladder (GFEPY: $0.87 \mathrm{mg} / \mathrm{mL} ;$ FTGMD: $3.04 \mathrm{mg} / \mathrm{mL}$; FSGLR: $3.35 \mathrm{mg} / \mathrm{mL}$ ) [26], skipjack tuna bone (GPDGR: $1.44 \mathrm{mg} / \mathrm{mL}$; AGPM: $1.68 \mathrm{mg} / \mathrm{mL}$ ) [16], and hairtail (Trichiurus japonicas) muscle (KA: $2.082 \mathrm{mg} / \mathrm{mL}$; AKG: $2.538 \mathrm{mg} / \mathrm{mL}$; IYG: $1.355 \mathrm{mg} / \mathrm{mL}$ ) [29]. However, $\mathrm{EC}_{50}$ values of TGP3 and TGP4 were higher than those of APs from protein hydrolysates of miiuy croakers muscle (FWKVV: $0.29 \mathrm{mg} / \mathrm{mL}$; FMPLH: $0.15 \mathrm{mg} / \mathrm{mL}$ ) [2] and swim bladder (FPYLRH: $0.34 \mathrm{mg} / \mathrm{mL}$; GIEWA: $0.30 \mathrm{mg} / \mathrm{mL}$ ) [26], monkfish muscle (FLHRP: $0.101 \mathrm{mg} / \mathrm{mL}$; LMGQW: $0.042 \mathrm{mg} / \mathrm{mL}$ ) [35], and croceine croaker scale (GPAGPAG: $0.099 \mathrm{mg} / \mathrm{mL}$; GFPSG: $0.151 \mathrm{mg} / \mathrm{mL}$ ) [6]. Superoxide anion radical can produce hydroxyl radical to cause oxidative stress because it and its metabolites can initiate lipid peroxidation, react with carbonyl compounds for producing toxic peroxy radicals, and inactivate enzyme activity. Under normal physiological conditions, superoxide dismutase 
(SOD) catalyzes the dismutation of superoxide anions into hydrogen peroxide and oxygen [37-39]. Therefore, TGP3 and TGP4 can assist SOD to reduce superoxide anion radical damage in organisms.

\section{ABTS Cation Radical Scavenging Activity}

As shown in Figure 5D, the ABTS cation radical scavenging rates of six APs (TGP1-TGP6) increased with evaluated concentration ranging $0.1-5.0 \mathrm{mg} / \mathrm{mL}$, but their activities were still lower than that of GSH at the same concentration. $\mathrm{EC}_{50}$ values of TGP3 and TGP4 were $0.96 \pm 0.08$ and $0.54 \pm 0.03 \mathrm{mg} / \mathrm{mL}$, respectively, which were significantly $(p<0.05)$ lower than those of TGP-1 $(3.28 \pm 0.17 \mathrm{mg} / \mathrm{mL})$, TGP-2 $(2.56 \pm 0.23 \mathrm{mg} / \mathrm{mL})$, TGP-5 $(2.54 \pm 0.17 \mathrm{mg} / \mathrm{mL})$, and TGP-6 $(1.86 \pm 0.15 \mathrm{mg} / \mathrm{mL})$, respectively. Furthermore, $\mathrm{EC}_{50}$ values of TGP3 and TGP4 were lower than those of APs from protein hydrolysates of skipjack tuna bone (GPDGR: $1.07 \mathrm{mg} / \mathrm{mL}$; AGPM: $1.48 \mathrm{mg} / \mathrm{mL}$ ) [16] and muscle (NFWWP: $0.84 \mathrm{mg} / \mathrm{mL}$; YFLWP: $3.08 \mathrm{mg} / \mathrm{mL}$ ) [2], skate cartilage (IVAGPQ: $1.29 \mathrm{mg} / \mathrm{mL} ;$ FIMGPY: $1.04 \mathrm{mg} / \mathrm{mL}$ ) [8], spotless smoothhound muscle (GAA $1.7541 \mathrm{mg} / \mathrm{mL}$; GFVG $1.3055 \mathrm{mg} / \mathrm{mL}$ ), and salmon (FLNEFLHV: $1.548 \mathrm{mg} / \mathrm{mL}$ ) [40]. ABTS is popularly used to measure the capacities of APs, and the finding indicated that six APs (TGP1-TGP6), especially TGP3 and TGP4, could effectually inhibit the chain reaction of ABTS cation radicals by converting them to the colorless form.

\subsubsection{Lipid Peroxidation Inhibition Ability}

As presented in Figure 6, the absorbance values of TGP3 and TGP4 solutions at $500 \mathrm{~nm}$ were significantly $(p<0.5)$ lower than those of other four APs (TGP1, TGP2, TGP5, and TGP6) and the blank control without antioxidant. However, the $500 \mathrm{~nm}$ absorbance values of TGP3 and TGP4 solutions were little greater than that of the positive control (GSH). The oxidative process is complicated in food and biological systems and embroiled in multifarious reactions for propagation of lipid radicals hydroperoxides [3,5]. Those data of TGP3 and TGP4 in the linoleic acid model system indicated that they have a strong ability to inhibit lipid peroxidation. In addition, these abilities of TGP3 and TGP4 were similar to that of GSH in the seven days incubation.

Molecular size plays a key role in the antioxidant capacities of APs [5,24]. Six APs (TGP1-TGP6) from protein hydrolysate of blood cockle (T. granosa) are tetrapeptide to hexapeptide with MWs ranging 442.48 Da-754.81 Da (Table 1). These data indicated that six APs could easily interact with free radicals to inhibit the lipid peroxidation. Furthermore, amino acid composition and sequence are believed to play major contributions to the activities of APs $[5,29,36]$. Hydrophobic amino acid residues, including aliphatic (Val, Leu, and Ile), aromatic (Phe, Trp, and Tyr), and sulfur-containing (Met and Cys) can play their functions on radical scavenging because of their high reactivity to hydrophobic PUFAs in lipid-rich foods $[26,41]$. Aromatic residues can donate protons to electron deficient radicals to keep ROS stable during the radical scavenging process [5]. Sulfur-containing amino acid residues (Met and Cys) might work as a reactive site, where the peptide could scavenge oxidants through the formation of a sulfoxide structure after oxidation to stop free-radical chain reactions [2,42-44]. Therefore, hydrophobic/aromatic amino acid residues in TGP3 (Met, Leu, and Phe) and TGP4 (Trp and Pro) should contribute to their activity through helping them to contact target radicals. Giménez et al. [45] and Zhu et al. [46] found that polar amino acid residues (Glu, Asp, and Lys) played a critical role in antioxidant activity including metal ion chelating and hydroxyl radical scavenging activities. Gly residue can make the peptide skeleton more flexible and its single hydrogen atom can serve as proton-donating to neutralize free radicals [47-49]. Therefore, polar amino acids including Asp and Glu residues in TGP3, and Asp residues in TGP4 could play a critical role in the lipid peroxidation inhibition activities.

\subsection{Effects of Thermal, $p H$, and Simulated Gastrointestinal (GI) Digestion Treatments on TGP3 and TGP4 Stability}

As shown in Figure 7A, heat treatments could influence the hydroxyl radical scavenging activity (expressed as $\mathrm{EC}_{50}$ ) of TGP3 and TGP4. When TGP3 and TGP4 were treated at 25,37 , and $60^{\circ} \mathrm{C}$ for 
$0.5 \mathrm{~h}$, their $\mathrm{EC}_{50}$ values on hydroxyl radical did not show a significant $(p>0.05)$ difference, but were significantly $(p<0.05)$ lower than those of sample treated at 80 and $100^{\circ} \mathrm{C}$ for $0.5 \mathrm{~h}$.
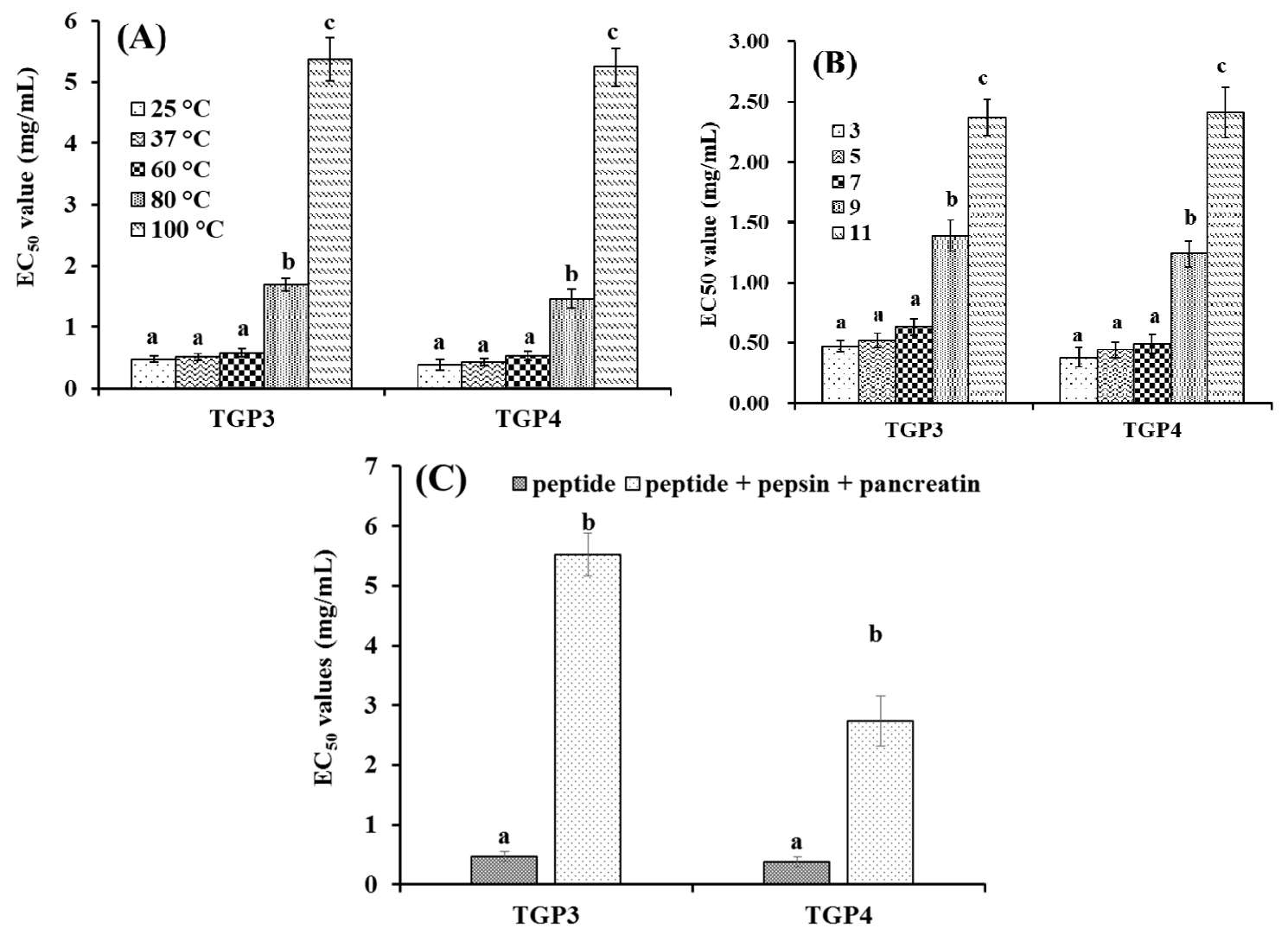

Figure 7. Hydroxyl radical scavenging activity of TGP3 and TGP4 subjected to heat treatments (A), $\mathrm{pH}$ treatments $(\mathbf{B})$, and simulated GI digestion treatments $(\mathbf{C})$. All data are expressed as mean $\pm \operatorname{SD}(n=3)$. a-c values with same letters indicate no significant difference of same sample $(p>0.05)$.

The $\mathrm{EC}_{50}$ values of TGP3 and TGP4 on hydroxyl radical treated at $\mathrm{pH} 3$ to 11 were presented in Figure 7B. There were no significant $(p>0.05)$ differences when the $\mathrm{pH}$ changed from 3 to 7 . However, $\mathrm{EC}_{50}$ values of TGP3 and TGP4 on hydroxyl radical in acidic and neutral conditions were significantly $(p<0.05)$ lower than those of alkaline conditions ( $\mathrm{pH} 9$ to 11$)$.

In response to simulated GI digestion, the hydroxyl radical scavenging activities of TGP3 and TGP4 are shown in Figure 7C. The $\mathrm{EC}_{50}$ values for TGP3 and TGP4 before simulated GI digestion (TGP3: $0.47 \pm 0.03 \mathrm{mg} / \mathrm{mL}$; TGP4: $0.38 \pm 0.04 \mathrm{mg} / \mathrm{mL})$ were significantly $(p<0.05)$ lower than those obtained after simulated GI digestion (TGP3: $5.52 \pm 0.36 \mathrm{mg} / \mathrm{mL}$; TGP4: $2.74 \pm 0.42 \mathrm{mg} / \mathrm{mL}$ ).

Heat treatment is a common method of food processing and APs are helpful to lengthen the food shelf-life if they can keep their activity after heating. Peptides with large-scale $\mathrm{pH}$ stability can be incorporated into diverse liquid products and keep their bioactivity. Therefore, thermal and $\mathrm{pH}$ stability of peptides are important indexes for their application in functional products, and characterization of those properties can help to design their potential processing parameters [15,50]. ATSHH from protein hydrolysate of sandfish (Arctoscopus japonicus) partially lost its DPPH radical scavenging activity when it was incubated at $50-90^{\circ} \mathrm{C}$. In addition, ATSHH bored moderate losses of activity under basic ( $\mathrm{pH} 10-12)$ and acidic ( $\mathrm{pH}$ 2) conditions [50]. However, there are no significant $(p>0.05)$ differences when WAFAPA and MYPGLA from blue-spotted stingray are incorporated during heat $\left(25-100{ }^{\circ} \mathrm{C}\right)$ and $\mathrm{pH}(3-11)$ treatments [15]. In the experiment, $\mathrm{EC}_{50}$ values of TGP3 and TGP4 on hydroxyl radical significantly $(p<0.005)$ increased at temperatures above $80^{\circ} \mathrm{C}$ and $\mathrm{pH}$ values higher than 9, which indicated that TGP3 and TGP4 were not suitable for high temperature treatment and basic $(\mathrm{pH}>9.0$ for $2.5 \mathrm{~h}$ ) food products. The capacity of TGP3 and TGP4 to resist GI digestion is one of 
the key requirements for their applications in vivo, which may tell whether they will be used as food ingredients or nutraceuticals in isolated forms. Then, simulated GI digestion is usually used to evaluate the fate of peptides before exploring their bioactivity and bioavailability in vivo [50]. In this assay, $\mathrm{EC}_{50}$ values of TGP3 and TGP4 with simulated GI digestion on hydroxyl radical were significantly $(p<0.05)$ increased (Figure 7C), which reflected that TGP3 and TGP4 are partially susceptible to be degradated by GI digestive enzymes. In addition, Figure 7C shows that the effect of GI digestion on TGP4 was significantly weaker than that on TGP3. The results were in accordance with the report by Segura-Campos et al. that bioactive peptides containing Pro residues generally stand up to degradation by GI digestive enzymes [51]. Taken together, TGP3 and TGP4 are unstable under high thermal food processing and cannot retain bioactivity under basic $\mathrm{pH}$ conditions.

\section{Experimental Section}

\subsection{Materials}

Blood cockle (T. granosa) was purchased from Fengmao market (Zhoushan, China) and authenticated by Professor Sheng-long Zhao (Zhejiang Ocean University, Zhoushan, China). Sephadex G-25, Sephadex G-15, GSH, bovine serum albumin (BSA), and DEAE-52 cellulose were purchased from Shanghai Source Poly Biological Technology Co., Ltd. (Shanghai, China). DPPH, phosphate buffered saline ( $\mathrm{pH}$ 7.2), 2,4,6-trinitrobenzenesulfonic acid solution (TNBS), and ABTS were bought from Sigma-Aldrich (Shanghai) Trading Co., Ltd. (China). Acetonitrile (LC grade) and trifluoroacetic acid (TFA) were purchased from Thermo Fisher Scientific Co., Ltd. (Shanghai, China). Six APs (TGP1 to TGP6) with purity of $98 \%$ were synthesized in Shanghai Apeptide Co. Ltd. (Shanghai, China).

\subsection{Preparation of Protein Hydrolysate (TGH) of Blood Cockle (T. granosa)}

The defatting process of blood cockle was carried out according to the previous methods [2,17]. Blood cockle internal organs were removed, and the resulting meat was rinsed and homogenized using a JJ-2 Kinematica (Jiangsu Jiangling Co., Ltd., Yancheng, China). The homogenate and isopropanol were mixed in a ratio of $1: 4(w / v)$ and stirred uninterrupted at $35^{\circ} \mathrm{C}$ for $2.5 \mathrm{~h}$, and the defatting process was performed three times. After that, the degreasing mixture was centrifuged at $9000 \mathrm{~g}$ for $20 \mathrm{~min}$ at $4{ }^{\circ} \mathrm{C}$. The supernatant was removed, and the sediment was freeze-dried and stored at $-20^{\circ} \mathrm{C}$.

The hydrolysis process was carried out using a two-enzyme system (Alcalase treatment for $1.5 \mathrm{~h}$ following Neutrase treatment for $1.5 \mathrm{~h})$. The defatted precipitate $(100 \mathrm{~g})$ was dissolved $(5 \%, w / v)$ in $0.05 \mathrm{M}$ Tris- $\mathrm{HCl}$ buffer solution ( $\mathrm{pH}$ 8.5) and hydrolyzed using Alcalase at $50.0^{\circ} \mathrm{C}$ with enzyme dose $1.5 \%(w / w)$ for $1.5 \mathrm{~h}$. After that, the $\mathrm{pH}$ of dispersions was changed with $\mathrm{HCl}$ solution $(1.0 \mathrm{M})$ and hydrolyzed using Neutrase at $\mathrm{pH} 7.0,55.0^{\circ} \mathrm{C}$ with enzyme dose $1.5 \%(w / w)$ for $1.5 \mathrm{~h}$. Afterwards, the hydrolysate was kept in a $95^{\circ} \mathrm{C}$ water bath for $10 \mathrm{~min}$ to inactivate proteases and centrifuged at $12,000 \mathrm{~g}$ for $15 \mathrm{~min}$. The resulted supernatant, referred to as TGH, was freeze-dried and stored at $-20{ }^{\circ} \mathrm{C}$.

The concentrations of TGH and hydrolysate fractions were expressed as $\mathrm{mg}$ protein/mL and determined by the dye binding method of Bradford (1976) with BSA as the standard protein [52].

\subsection{Isolation of $A P s$ from $T G H$}

\subsubsection{Fractionation of TGH}

TGH was fractionated by ultrafiltration using Labscale TFF System of Millipor Ltd. (Billerica, MA, USA) with 3, 5, and $10 \mathrm{kDa}$ MWCO membranes, and four fractions, termed as TGH-I $(<3 \mathrm{kDa})$, TGH-II (3-5 kDa), TGH-III (5-10 kDa), and TGH-IV (>10 kDa), were collected and freeze-dried. 


\subsubsection{Chromatography Isolation of APs from TGH-I}

$10 \mathrm{~mL}$ of TGH-I solution ( $40.0 \mathrm{mg}$ protein $/ \mathrm{mL}$ ) was added into a DEAE-52 cellulose column $(2.0 \times 100 \mathrm{~cm})$ pretreated with DW, and stepwise eluted with $150 \mathrm{~mL} \mathrm{DW}, 0.1 \mathrm{M} \mathrm{NaCl}, 0.5 \mathrm{M} \mathrm{NaCl}$, and $1.0 \mathrm{M} \mathrm{NaCl}$ solution at a flow rate of $1.0 \mathrm{~mL} / \mathrm{min}$, respectively. Each eluate $(5 \mathrm{~mL})$ was monitored at $214 \mathrm{~nm}$. Finally, six fractions (TGH-I-1 to TGH-I-6) were pooled on chromatographic peak and freeze-dried.

$5 \mathrm{~mL}$ of TGH-I-5 solution (30.0 mg protein $/ \mathrm{mL}$ ) was loaded onto a Sephadex G-25 column $(2.5 \times 200 \mathrm{~cm})$ eluted with DW at a flow rate of $0.8 \mathrm{~mL} / \mathrm{min}$. Each eluate $(3 \mathrm{~mL})$ was collected and monitored at $214 \mathrm{~nm}$, and TGH-I-5B solution $(5 \mathrm{~mL}, 25.0 \mathrm{mg}$ protein $/ \mathrm{mL})$ was further separated by a Sephadex G-15 column $(2.0 \times 180 \mathrm{~cm})$ at a flow rate of $0.6 \mathrm{~mL} / \mathrm{min}$. Each eluate $(3 \mathrm{~mL})$ was collected and monitored at $214 \mathrm{~nm}$, and four subfractions (TGH-I-5B1, TGH-I-5B2, TGH-I-5B3, and TGH-I-5B4) were collected and lyophilized.

Finally, TGH-I-5B3 was purified on an Agilent 1260 HPLC system (Agilent Ltd., Santa Rosa, CA, USA) with a Zorbax C-18 column $(4.6 \times 250 \mathrm{~mm})$. The sample was eluated at a flow rate of $0.8 \mathrm{~mL} / \mathrm{min}$ with a linear gradient of acetonitrile from $0 \%$ to $50 \%$ in $0-25 \mathrm{~min}$ in $0.1 \%$ TFA. Six APs (TGP1 to TGP6) were isolated on $214 \mathrm{~nm}$ absorbance and lyophilized.

\subsection{Degree of Hydrolysis (DH)}

DH analysis was performed according to the previously described method [6]. The hydrolysate $(50 \mu \mathrm{L})$ was mixed with $0.5 \mathrm{~mL}$ of $0.2 \mathrm{M}$ phosphate buffered saline (PBS), $\mathrm{pH} 8.2$ and $0.5 \mathrm{~mL}$ of $0.05 \%$ 2,4,6-trinitrobenzene sulfonic acid (TNBS) reagent. TNBS was freshly prepared before use by diluting with DW water. The mixture was incubated at $50{ }^{\circ} \mathrm{C}$ for $1 \mathrm{~h}$ in a water bath. The reaction was stopped by adding $1 \mathrm{~mL}$ of $0.1 \mathrm{M} \mathrm{HCl}$ and incubated at room temperature for $30 \mathrm{~min}$. The absorbance was monitored at $420 \mathrm{~nm}$. L-Leucine was used as a standard. To determine the total amino acid content, TGH was completely hydrolyzed with $6 \mathrm{M} \mathrm{HCl}$ with a sample to acid ratio of $1: 100$ at $120^{\circ} \mathrm{C}$ for $24 \mathrm{~h}$. $\mathrm{DH}(\%)$ was calculated using the following equation:

$$
\mathrm{DH}=\left[\left(\mathrm{A}_{\mathrm{t}}-\mathrm{A}_{0}\right) /\left(\mathrm{A}_{\max }-\mathrm{A}_{0}\right)\right] \times 100
$$

where $A_{t}$ is the amount of a-amino acids released at time $t, A_{0}$ is the amount of amino acids in the supernatant at $0 \mathrm{~h}$, and Amax is the total amount of a-amino acids obtained after acid hydrolysis at $120^{\circ} \mathrm{C}$ for $24 \mathrm{~h}$.

\subsection{Antioxidant Activity}

\subsubsection{Radical Scavenging Activity}

The DPPH radical, hydroxyl radical, superoxide anion radical, and ABTS cation radical scavenging activities were measured according to the previous methods $[6,53,54]$. The results were expressed as a half elimination ratio $\left(\mathrm{EC}_{50}\right)$ defined as the concentration by which a sample caused a $50 \%$ decrease of the initial concentration of DPPH radical, hydroxyl radical, superoxide anion radical, and ABTS cation radical, respectively, and the calculation method of $\mathrm{EC}_{50}$ was according to linear relationship of radical scavenging rates and concentrations of samples $[6,26]$.

DPPH Radical Scavenging Activity

Two millilitres of samples consisting of DW and different concentrations of the analytes were placed in cuvettes, and $500 \mu \mathrm{L}$ of an ethanolic solution of DPPH $(0.02 \%)$ and $1.0 \mathrm{~mL}$ of ethanol were added. A control sample containing the DPPH solution without the sample was also prepared. In the 
blank, the DPPH solution was substituted with ethanol. The antioxidant activity of the sample was evaluated using the inhibition percentage of the DPPH radical with the following equation:

$$
\text { DPPH radical scavenging activity }(\%)=\left(\mathrm{A}_{0}+\mathrm{A}_{\mathrm{b}}-\mathrm{A}\right) / \mathrm{A}_{0} \times 100 \%
$$

where $A$ is the absorbance rate of the sample, $A_{0}$ is the control group absorbance, and $A_{b}$ is the blank absorbance.

\section{Hydroxyl Radical Scavenging Activity}

First, $1.0 \mathrm{~mL}$ of a $1.87 \mathrm{mM}$ 1,10-phenanthroline solution and $2.0 \mathrm{~mL}$ of the sample were added to a screw-capped tube and mixed. Then, $1.0 \mathrm{~mL}$ of a $\mathrm{FeSO}_{4} \cdot 7 \mathrm{H}_{2} \mathrm{O}$ solution $(1.87 \mathrm{mM})$ was added to the mixture. The reaction was initiated by adding $1.0 \mathrm{~mL}$ of $\mathrm{H}_{2} \mathrm{O}_{2}(0.03 \%, v / v)$. After being incubated at $37^{\circ} \mathrm{C}$ for $60 \mathrm{~min}$ in a water bath, the absorbance of the reaction mixture was measured at $536 \mathrm{~nm}$ against a reagent blank. The reaction mixture without any antioxidant was used as the negative control, and a mixture without $\mathrm{H}_{2} \mathrm{O}_{2}$ was used as the blank. The hydroxyl radical scavenging activity was calculated using the following formula:

$$
\text { Hydroxyl radical scavenging activity }(\%)=\left[\left(\mathrm{A}_{\mathrm{s}}-\mathrm{A}_{\mathrm{n}}\right) /\left(\mathrm{A}_{\mathrm{b}}-\mathrm{A}_{\mathrm{n}}\right)\right] \times 100 \%
$$

where $A_{s}, A_{n}$, and $A_{b}$ are the absorbance values determined at $536 \mathrm{~nm}$ of the sample, the negative control, and the blank after the reaction, respectively.

\section{Superoxide Anion Radical Scavenging Activity}

The superoxide anions were generated in $1 \mathrm{~mL}$ of nitrotetrazolium blue chloride $(2.52 \mathrm{mM})$, $1 \mathrm{~mL}$ of nicotinamide adenine dinucleotide hydride (NADH) $(624 \mathrm{mM})$ and $1 \mathrm{~mL}$ of different sample concentrations. The reaction was initiated by adding $1 \mathrm{ml}$ of phenazine methosulphate solution $(120 \mu \mathrm{M})$ to the reaction mixture. The absorbance was measured at $560 \mathrm{~nm}$ against the corresponding blank after $5 \mathrm{~min}$ incubation at $25^{\circ} \mathrm{C}$. The superoxide anion radical scavenging capacity was calculated using the following equation:

Superoxide anion radical scavenging activity $(\%)=\left[\left(\mathrm{A}_{\text {control }}-\mathrm{A}_{\text {sample }}\right) / \mathrm{A}_{\text {control }}\right] \times 100 \%$

where $A_{\text {control }}$ is the absorbance without sample and $A_{\text {sample }}$ is the absorbance with sample.

ABTS Cation Radical Scavenging Activity

The ABTS radical cation was generated by mixing ABTS stock solution $(7 \mathrm{mM})$ with potassium persulphate $(2.45 \mathrm{mM})$. The mixture was left in the dark at room temperature for $16 \mathrm{~h}$. The ABTS radical solution was diluted in $5 \mathrm{mM}$ PBS pH 7.4, to an absorbance of $0.70 \pm 0.02$ at $734 \mathrm{~nm}$. One milliliter of diluted ABTS radical solution was mixed with one milliliter of different concentrations of samples. $10 \mathrm{~min}$ later, the absorbance was measured at $734 \mathrm{~nm}$ against the corresponding blank. The ABTS scavenging activity of samples was calculated using the following equation:

$$
\text { ABTS scavenging activity }(\%)=\left[\left(\mathrm{A}_{\text {control }}-\mathrm{A}_{\text {sample }}\right) / \mathrm{A}_{\text {control }}\right] \times 100 \%
$$

where $\mathrm{A}_{\text {control }}$ is the absorbance without sample and $\mathrm{A}_{\text {sample }}$ is the absorbance with sample.

\subsubsection{Lipid Peroxidation Inhibition Assay}

The lipid peroxidation inhibition and radical scavenging assays of TGP1 to TGP6 were measured according to the previous method [6,55]. In brief, a sample $(5.0 \mathrm{mg})$ was dissolved in $10 \mathrm{~mL}$ of $50 \mathrm{mM}$ phosphate buffer ( $\mathrm{pH} 7.0$ ), and added to a solution of $0.13 \mathrm{~mL}$ of linoleic acid and $10 \mathrm{~mL}$ of $99.5 \%$ ethanol. Then, the total volume was adjusted to $25 \mathrm{~mL}$ with DW. The mixture was incubated in a conical 
flask with a screw cap at $40{ }^{\circ} \mathrm{C}$ in a dark room and the degree of oxidation was evaluated by measuring the ferric thiocyanate values. The reaction solution $(100 \mu \mathrm{L})$ incubated in the linoleic acid model system was mixed with $4.7 \mathrm{~mL}$ of $75 \%$ ethanol, $0.1 \mathrm{~mL}$ of $30 \%$ ammonium thiocyanate, and $0.1 \mathrm{~mL}$ of $20 \mathrm{mM}$ ferrous chloride solution in $3.5 \% \mathrm{HCl}$. After $3 \mathrm{~min}$, the thiocyanate value was measured by reading the absorbance at $500 \mathrm{~nm}$ following color development with $\mathrm{FeCl}_{2}$ and thiocyanate at different intervals during the incubation period at $40{ }^{\circ} \mathrm{C}$.

\subsection{Amino Acid Sequence and Molecular Mass Analysis}

Amino acid sequences and molecular masses of TGP1 to TGP6 were measured on the previous method [26,56]. TGP1 to TGP6 were subjected to N-terminal amino acid sequencing on an Applied Biosystems 494 protein sequencer (Perkin Elmer/Applied Biosystems Inc., Foster City, CA, USA). Edman degradation was performed according to the standard program supplied by Applied Biosystems. Accurate molecular masses of TGP1 to TGP6 were determined using a Q-TOF mass spectrometer (Micromass, Waters, Milford, MA, USA) coupled with an ESI source.

\subsection{Stability Properties of TGP3 and TGP4 against Heat, $p H$, and Simulated GI Digestion Treatments}

Stability of TGP3 and TGP4 were measured according to the previous method with minor modifications [49]. A temperature-controlled water bath at $25,37,60,80$, or $100{ }^{\circ} \mathrm{C}$ for $0.5 \mathrm{~h}$ was used

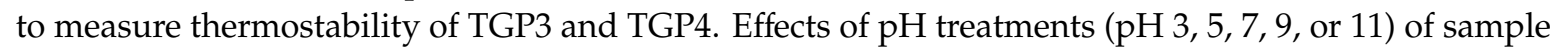
solutions incubated at $25^{\circ} \mathrm{C}$ for $2.5 \mathrm{~h}$ were assessed to analyze the $\mathrm{pH}$ stability of TGP3 and TGP4. A two-stage digestion model (pepsin for $1.0 \mathrm{~h}+$ pancreatin for $2.0 \mathrm{~h}$ ) was applied to simulate GI digestion of TGP3 and TGP4. Hydroxyl radical scavenging activities (EC ${ }_{50}$ value) of the treated TGP3 and TGP4 were measured according to the previous methods $[6,26]$.

\subsection{Statistical Analysis}

The data are expressed as the mean $\pm \mathrm{SD}(\mathrm{n}=3)$. A one-way analysis of variance (ANOVA) test for differences between means of each group was applied to analyze data using SPSS 19.0 (Statistical Program for Social Sciences, SPSS Corporation, Chicago, IL, USA). A P-value of less than 0.05 was considered statistically significant.

\section{Conclusions}

In the experiment, blood cockle (T. granosa) was hydrolyzed under a two-enzyme system (Alcalase treatment for $1.5 \mathrm{~h}$ following Neutrase treatment for $1.5 \mathrm{~h}$ ) and six APs (TGP1-TGP6) were isolated from the resulting hydrolysate (TGH) and identified as EPLSD (TGP1), WLDPDG (TGP2), MDLFTE (TGP3), WPPD (TGP4), EPVV (TGP5), and CYIE (TGP6), respectively. Six APs (TGP1-TGP6), especially TGP3 and TGP4, exhibited high radical scavenging and lipid peroxidation inhibition capabilities. However, TGP3 and TGP4 are unstable and cannot retain antioxidant activity at high temperatures $\left(>80^{\circ} \mathrm{C}\right.$ for $0.5 \mathrm{~h}$ ), basic $\mathrm{pH}$ conditions $(\mathrm{pH}>9$ for $2.5 \mathrm{~h}$ ), or during simulated GI digestion. Therefore, TGP3 and TGP4 may be more suitable to serve as nutraceutical candidates in isolated forms than as food ingredient candidates. In addition, in vivo experiments to elucidate the antioxidant mechanisms of the six APs (TGP1-TGP6) need to be performed in future.

Author Contributions: C.-F.C. and B.W. conceived and designed the experiments. X.-R.Y., Y.-T.Q., and Y.-Q.Z. performed the experiments and analyzed the data. C.-F.C. and B.W. contributed the reagents, materials, and analytical tools and wrote the paper.

Funding: This work was funded by the National Natural Science Foundation of China (No. 31872547), International S\&T Cooperation Program of China (No. 2012DFA30600), and Zhejiang Province Public Technology Research Project (No. LGN18D060002).

Conflicts of Interest: The authors declare no conflicts of interest. 


\section{References}

1. Lim, S.; Choi, A.H.; Kwon, M.; Joung, E.J.; Shin, T.; Lee, S.G.; Kim, N.G.; Kim, H.R. Evaluation of antioxidant activities of various solvent extract from Sargassum serratifolium and its major antioxidant components. Food Chem. 2019, 278, 178-184. [CrossRef]

2. He, Y.; Pan, X.; Chi, C.F.; Sun, K.L.; Wang, B. Ten new pentapeptides from protein hydrolysate of miiuy croaker (Miichthys miiuy) muscle: Preparation, identification, and antioxidant activity evaluation. LWT Food Sci. Technol. 2019, 105, 1-8. [CrossRef]

3. Luisi, G.; Stefanucci, A.; Zengin, G.; Dimmito, M.P.; Mollica, A. Anti-oxidant and tyrosinase inhibitory in vitro activity of amino acids and small peptides: New hints for the multifaceted treatment of neurologic and metabolic disfunctions. Antioxidants 2018, 8, 7. [CrossRef] [PubMed]

4. Harnedy, P.A.; O'Keeffe, M.B.; FitzGerald, R.J. Fractionation and identification of antioxidant peptides from an enzymatically hydrolysed Palmaria palmata protein isolate. Food Res. Int. 2017, 100, 416-422. [CrossRef] [PubMed]

5. Sila, A.; Bougatef, A. Antioxidant peptides from marine by-products: Isolation, identification and application in food systems. A review. J. Funct. Foods 2016, 21, 10-26. [CrossRef]

6. Wang, B.; Wang, Y.M.; Chi, C.F.; Hu, F.Y.; Deng, S.G.; Ma, J.Y. Isolation and characterization of collagen and antioxidant collagen peptides from scales of croceine croaker (Pseudosciaena crocea). Mar. Drugs 2013, 11, 4641-4661. [CrossRef]

7. Shazly, A.B.; He, Z.; El-Aziz, M.A.; Zeng, M.; Zhang, S.; Qin, F.; Chen, J. Fractionation and identification of novel antioxidant peptides from buffalo and bovine casein hydrolysates. Food Chem. 2017, 232, 753-762. [CrossRef] [PubMed]

8. Pan, X.; Zhao, Y.Q.; Hu, F.Y.; Wang, B. Preparation and identification of antioxidant peptides from protein hydrolysate of skate (Raja porosa) cartilage. J. Funct. Foods 2016, 25, 220-230. [CrossRef]

9. Stefanucci, A.; Luisi, G.; Zengin, G.; Macedonio, G.; Dimmito, M.P.; Novellino, E.; Mollica, A. Discovery of arginine-containing tripeptides as a new class of pancreatic lipase inhibitors. Future Med. Chem. 2019, 11, 5-19. [CrossRef]

10. Harnedy, P.A.; FitzGerald, R.J. Bioactive peptides from marine processing waste and shellfish: A review. J. Funct. Foods 2012, 4, 6-24. [CrossRef]

11. Zhao, W.H.; Chi, C.F.; Zhao, Y.Q.; Wang, B. Preparation, physicochemical and antioxidant properties of acidand pepsin-soluble collagens from the swim bladders of miiuy croaker (Miichthys miiuy). Mar. Drugs 2018, 16, 161. [CrossRef] [PubMed]

12. Stefanucci, A.; Dimmito, M.P.; Zengin, G.; Luisi, G.; Mirzaie, S.; Novellino, E.; Mollica, A. Discovery of novel amide tripeptides as pancreatic lipase inhibitors by virtual screening. New J. Chem. 2019, 43, 3208-3217. [CrossRef]

13. Jin, J.E.; Ahb, C.B.; Je, J.Y. Purification and characterization of antioxidant peptides from enzymatically hydrolyzed ark shell (Scapharca subcrenata). Process Biochem. 2018, 72, 170-176. [CrossRef]

14. Zhao, S.; Cheng, Q.; Peng, Q.; Yu, X.; Yin, X.; Liang, M.; Ma, C.W.; Huang, Z.; Jia, W. Antioxidant peptides derived from the hydrolyzate of purple sea urchin (Strongylocentrotus nudus) gonad alleviate oxidative stress in Caenorhabditis elegans. J. Funct. Foods 2018, 48, 594-604. [CrossRef]

15. Wong, F.C.; Xiao, J.; Ong, M.G.L.; Pang, M.J.; Wong, S.J.; Teh, L.K.; Chai, T.T. Identification and characterization of antioxidant peptides from hydrolysate of blue-spotted stingray and their stability against thermal, $\mathrm{pH}$ and simulated gastrointestinal digestion treatments. Food Chem. 2019, 271, 614-622. [CrossRef]

16. Yang, X.R.; Zhao, Y.Q.; Qiu, Y.T.; Chi, C.F.; Wang, B. Preparation and characterization of gelatin and antioxidant peptides from gelatin hydrolysate of skipjack tuna (Katsuwonus pelamis) bone stimulated by in vitro gastrointestinal digestion. Mar. Drugs 2019, 17, 78. [CrossRef] [PubMed]

17. Chi, C.F.; Hu, F.Y.; Wang, B.; Li, T.; Ding, G.F. Antioxidant and anticancer peptides from protein hydrolysate of blood clam (Tegillarca granosa) muscle. J. Funct. Foods 2015, 15, 301-313. [CrossRef]

18. Guo, X.S.; Li, Y. Marine Chinese Traditional Medicines; Sciences Press: Beijing, China, 2003; pp. $138-141$.

19. Han, Z.W.; Yao, R.Y.; Chen, S.G.; Wang, C.B.; Han, B.Q. Extract from Arca granosa Linnaeus inbibits proliferation of human tumor cell lines of kidney and lung origin. Acta Pharmacol. Sin. 2006, 27, 354. 
20. Chi, C.F.; Wang, B.; Wang, Y.M.; Zhang, B.; Deng, S.G. Isolation and characterization of three antioxidant peptides from protein hydrolysate of bluefin leatherjacket (Navodon septentrionalis) heads. J. Funct. Foods 2015, 12, 1-10. [CrossRef]

21. Zhang, Y.; Duan, X.; Zhuang, Y. Purification and characterization of novel antioxidant peptides from enzymatic hydrolysates of tilapia (Oreochromis niloticus) skin gelatin. Peptides 2012, 38, 13-21. [CrossRef]

22. Ahn, C.B.; Kim, J.G.; Je, J.Y. Purification and antioxidant properties of octapeptide from salmon byproduct protein hydrolysate by gastrointestinal digestion. Food Chem. 2014, 147, 78-83. [CrossRef]

23. Chi, C.F.; Cao, Z.H.; Wang, B.; Hu, F.Y.; Li, Z.R.; Zhang, B. Antioxidant and functional properties of collagen hydrolysates from spanish mackerel skin as influenced by average molecular weight. Molecules 2014, 19, 11211-11230. [CrossRef] [PubMed]

24. Li, Z.; Wang, B.; Chi, C.; Gong, Y.; Luo, H.; Ding, G. Influence of average molecular weight on antioxidant and functional properties of cartilage collagen hydrolysates from Sphyrna lewini, Dasyatis akjei and Raja porosa. Food Res. Int. 2013, 51, 283-293. [CrossRef]

25. Wang, B.; Li, Z.R.; Chi, C.F.; Zhang, Q.H.; Luo, H.Y. Preparation and evaluation of antioxidant peptides from ethanol-soluble proteins hydrolysate of Sphyrna lewini muscle. Peptides 2012, 36, 240-250. [CrossRef]

26. Zhao, W.H.; Luo, Q.B.; Pan, X.; Chi, C.F.; Sun, K.L.; Wang, B. Preparation, identification, and activity evaluation of ten antioxidant peptides from protein hydrolysate of swim bladders of miiuy croaker (Miichthys miiuy). J. Funct. Foods 2018, 47, 503-511. [CrossRef]

27. Wang, B.; Li, L.; Chi, C.F.; Ma, J.H.; Luo, H.Y.; Xu, Y.F. Purification and characterisation of a novel antioxidant peptide derived from blue mussel (Mytilus edulis) protein hydrolysate. Food Chem. 2013, 138, 1713-1719. [CrossRef] [PubMed]

28. Hu, F.Y.; Chi, C.F.; Wang, B.; Deng, S.G. Two novel antioxidant nonapeptides from protein hydrolysate of skate (Raja porosa) muscle. Mar. Drugs 2015, 13, 1993-2009. [CrossRef] [PubMed]

29. Chi, C.F.; Wang, B.; Hu, F.Y.; Wang, Y.M.; Zhang, B.; Deng, S.G.; Wu, C.W. Purification and identification of three novel antioxidant peptides from protein hydrolysate of bluefin leatherjacket (Navodon septentrionalis) skin. Food Res. Int. 2015, 73, 124-129. [CrossRef]

30. Cai, L.; Wu, X.; Zhang, Y.; Li, X.; Ma, S.; Li, J. Purification and characterization of three antioxidant peptides from protein hydrolysate of grass carp (Ctenopharyngodon idella) skin. J. Funct. Foods 2015, 16, $234-242$. [CrossRef]

31. You, L.; Zhao, M.; Regenstein, J.M.; Ren, J. Purification and identification of antioxidative peptides from loach (Misgurnus anguillicaudatus) protein hydrolysate by consecutive chromatography and electrospray ionizationmass spectrometry. Food Res. Int. 2010, 43, 1167-1173. [CrossRef]

32. Yang, X.R.; Zhang, L.; Ding, D.G.; Chi, C.F.; Wang, B.; Huo, J.C. Preparation, identification, and activity evaluation of eight antioxidant peptides from protein hydrolysate of hairtail (Trichiurus japonicas) muscle. Mar. Drugs 2019, 17, 23. [CrossRef]

33. Rajapakse, N.; Mendis, E.; Byun, H.G.; Kim, S.K. Purification and in vitro antioxidative effects of giant squid muscle peptides on free radical-mediated oxidative systems. J. Nutr. Biochem. 2005, 9, 562-569. [CrossRef]

34. Ranathunga, S.; Rajapakse, N.; Kim, S.K. Purification and characterization of antioxidantative peptide derived from muscle of conger eel (Conger myriaster). Eur. Food Res. Technol. 2006, 222, 310-315. [CrossRef]

35. Chi, C.F.; Wang, B.; Wang, Y.M.; Deng, S.G.; Ma, J.H. Isolation and characterization of three antioxidant pentapeptides from protein hydrolysate of monkfish (Lophius litulon) muscle. Food Res. Int. 2014, 55, 222-228. [CrossRef]

36. Wang, B.; Gong, Y.D.; Li, Z.R.; Yu, D.; Chi, C.F.; Ma, J.Y. Isolation and characterisation of five novel antioxidant peptides from ethanol-soluble proteins hydrolysate of spotless smoothhound (Mustelus griseus) muscle. J. Funct. Foods 2014, 6, 176-185. [CrossRef]

37. Castellano, I.; Di Maro, A.; Ruocco, M.R.; Chambery, A.; Parente, A.; Di Martino, M.T.; Parlato, G.; Masullo, M.; De Vendittis, E. Psychrophilic superoxide dismutase from Pseudoalteromonas haloplanktis: biochemical characterization and identification of a highly reactive cysteine residue. Biochimie 2006, 88, 1377-1389.

38. Li, L.Y.; Zhao, Y.Q.; He, Y.; Chi, C.F.; Wang, B. Physicochemical and antioxidant properties of acid- and pepsin-soluble collagens from the scales of miiuy croaker (Miichthys miiuy). Mar. Drugs 2018, 16, 394. [CrossRef] [PubMed] 
39. Zhao, Y.Q.; Zeng, L.; Yang, Z.S.; Huang, F.F.; Ding, G.F.; Wang, B. Anti-fatigue effect by peptide fraction from protein hydrolysate of croceine croaker (Pseudosciaena crocea) swim bladder through inhibiting the oxidative reactions including DNA damage. Mar. Drugs 2016, 14, 221. [CrossRef] [PubMed]

40. Ahn, C.B.; Cho, Y.S.; Je, J.Y. Purification and anti-inflammatory action of tripeptide from salmon pectoral fin byproduct protein hydrolysate. Food Chem. 2015, 168, 151-156. [CrossRef] [PubMed]

41. Chi, C.F.; Hu, F.Y.; Wang, B.; Li, Z.R.; Luo, H.Y. Influence of amino acid compositions and peptide profiles on antioxidant capacities of two protein hydrolysates from skipjack tuna (Katsuwonus pelamis) dark muscle. Mar. Drugs 2015, 13, 2580-2601. [CrossRef]

42. Wu, R.; Wu, C.; Liu, D.; Yang, X.; Huang, J.; Zhang, J.; Liao, B.; He, H. Antioxidant and anti-freezing peptides from salmon collagen hydrolysate prepared by bacterial extracellular protease. Food Chem. 2018, 248, 346-352. [CrossRef]

43. Jacob, C. A scent of therapy: pharmacological implications of natural products containing redox-active sulfur atoms. Nat. Prod. Rep. 2006, 23, 851-863. [CrossRef] [PubMed]

44. Castellano, I.; Seebeck, F.P. On ovothiol biosynthesis and biological roles: from life in the ocean to therapeutic potential. Nat. Prod. Rep. 2018, 35, 1241-1250. [CrossRef] [PubMed]

45. Giménez, B.; Aleman, A.; Montero, P.; Gomez-Guillen, M.C. Antioxidant and functional properties of gelatin hydrolysates obtained from skin of sole and squid. Food Chem. 2009, 114, 976-983. [CrossRef]

46. Zhu, C.Z.; Zhang, W.G.; Zhou, G.H.; Xu, X.L.; Kang, Z.L.; Yin, Y. Isolation and identification of antioxidant peptides from Jinhua ham. J. Agric. Food Chem. 2013, 61, 1265-1271. [CrossRef] [PubMed]

47. Li, X.R.; Chi, C.F.; Li, L.; Wang, B. Purification and identification of antioxidant peptides from protein hydrolysate of scalloped hammerhead (Sphyrna lewini) cartilage. Mar. Drugs 2017, 15, 61. [CrossRef]

48. Nimalaratne, C.; Bandara, N.; Wu, J. Purification and characterization of antioxidant peptides from enzymatically hydrolyzed chicken egg white. Food Chem. 2015, 188, 467-472. [CrossRef]

49. Tao, J.; Zhao, Y.Q.; Chi, C.F.; Wang, B. Bioactive peptides from cartilage protein hydrolysate of spotless smoothhound and their antioxidant activity In vitro. Mar. Drugs 2018, 16, 100. [CrossRef]

50. Jang, H.L.; Liceaga, A.M.; Yoon, K.Y. Purification, characterisation and stability of an antioxidant peptide derived from sandfish (Arctoscopus japonicus) protein hydrolysates. J. Funct. Foods 2016, 20, 433-442. [CrossRef]

51. Segura-Campos, M.; Chel-Guerrero, L.; Betancur-Ancona, D.; Hernandez-Escalante, V.M. Bioavailability of bioactive peptides. Food Rev. Int. 2011, 27, 213-226. [CrossRef]

52. Bradford, M.M. A rapid and sensitive method for the quantification of microgram quantities of protein utilizing the principle of protein-dye binding. Anal. Biochem. 1976, 72, 248-254. [CrossRef]

53. Trampetti, F.; Pereira, C.; Rodrigues, M.J.; Celaj, O.; D'Abrosca, B.; Zengin, G.; Mollica, A.; Stefanucci, A.; Custódio, L. Exploring the halophyte Cistanche phelypaea (L.) Cout as a source of health promoting products: In vitro antioxidant and enzyme inhibitory properties, metabolomic profile and computational studies. J. Pharm. Biomed. Anal. 2019, 165, 119-128. [CrossRef] [PubMed]

54. Li, Z.; Wang, B.; Zhang, Q.; Qu, Y.; Xu, H.; Li, G. Preparation and antioxidant property of extract and semipurified fractions of Caulerpa racemosa. J. Appl. Phycol. 2012, 24, 1527-1536. [CrossRef]

55. Zhang, J.B.; Wang, Y.M.; Chi, C.F.; Sun, K.L.; Wang, B. Eight peptides from collagen hydrolysate fraction of Spanish mackerel (Scomberomorous niphonius) skin: Isolation, identification, and antioxidant activity in vitro. Mar. Drugs 2019, 17, 224. [CrossRef] [PubMed]

56. Zhao, Y.Q.; Zhang, L.; Tao, J.; Chi, C.F.; Wang, B. Isolation, identification, and antihypertensive activity evaluation of eight peptides from the protein hydrolysate of Antarctic krill (Euphausia superba). Food Res. Int. 2019, 121, 197-204. [CrossRef]

(C) 2019 by the authors. Licensee MDPI, Basel, Switzerland. This article is an open access article distributed under the terms and conditions of the Creative Commons Attribution (CC BY) license (http://creativecommons.org/licenses/by/4.0/). 